Balcerzak A.P., Pietrzak M., Research and development expenditures and quality of life in European Union countries, „Ekonomia i Prawo. Economics and Law”, Polszakiewicz B., Boehlke J. (ed.), Vol. 14, No. 3/2015, pp. 285-302. DOI: http://dx.doi.org/10.12775/EiP.2015.018.

\author{
Adam P. Balcerzak*, Michat Barnard Pietrzak ${ }^{* *}$
}

\title{
RESEARCH AND DEVELOPMENT EXPENDITURES AND QUALITY OF LIFE IN EUROPEAN UNION COUNTRIES
}

\author{
SUMMARY
}

The improvement of people's quality of life is currently considered as the main responsibility of every government. Due to the emergence of knowledge-based economy, it is commonly believed that investments in research and development $(\mathrm{R} \& \mathrm{D})$ at a given level are a necessary condition for creating growth-based on innovations, thus supporting welfare in developed countries. In this context, the article is devoted to the analysis of influence of $\mathrm{R} \& \mathrm{D}$ expenditures on the quality of life in the European Union countries. As the main measure of the quality of life Human Development Index was utilized. Thus, the article can be considered as a contribution to the discussion on the potential of HDI index for measuring the quality of life in the case of narrow group of relatively developed countries. In the empirical part of the paper, panel data modeling fulfilling the postulates of dynamic estimation was used. The research was done for EU countries for the period 2004-2010. The empirical part takes into consideration the structural

* Adam P. Balcerzak, Nicolaus Copernicus University, Faculty of Economic Sciences and Management, Department of Economics, ul. Gagarina 13A, 87-100 Toruń, Poland, phone: +48 5661146 23, e-mail: adam.balcerzak@umk.pl (corresponding author).

** Michał Bernard Pietrzak, Nicolaus Copernicus University, Faculty of Economic Sciences and Management, Department of Econometrics and Statistics, ul. Gagarina 13A, 87-100 Toruń, Poland, phone: +48 5661146 06, e-mail: michal.pietrzak@umk.pl. 
diversity between "old" and "new" members of the EU. First of all, the results can be treated as a voice confirming the usefulness of HDI as a measure of quality of life also from the perspective of narrow group of highly developed countries. Then, the research confirms the positive influence of R\&D on European welfare only in the case of highly developed "old" member.

Keywords: European Union; HDI; research and development expenditures; dynamic panel model

JEL Classification: I3; I31; F63

\section{INTRODUCTION}

Creating conditions for improvement of people's quality of life, regardless of common normative differences among university economists and political decision makers, is considered as the universal responsibility of every government. As a result, research concerning the determinants of the quality of life and efforts to propose a method for its measurement are considered as the core of contemporary applied macroeconomics. Currently, it is commonly believed that in the case of developed countries, the main determinant influencing their future welfare is the effectiveness of their policies in supporting the abilities of the economies to utilize the potential of knowledge-based economy ${ }^{1}$. At the same time, the policy decision makers looking for simple "rules" or "policies" tend to argue that reaching the research and development expenditure $(\mathrm{R} \& \mathrm{D})$ at a given level is a necessary, and commonly implicitly assumed sufficient, condition to create growth based on innovations, thus support long term welfare of the citizens. This approach could be seen in many

${ }^{1}$ M. Madrak-Grochowska, The Knowledge-based Economy as a Stage in the Development of the Economy, "Oeconomia Copernicana", Vol. 6, No. 2/2015, pp. 7-21; E. Jantoń-Drozdowska, M. Majewska, Effectiveness of Higher Education in the European Union Countries in Context of National Competitiveness, "Equilibrium. Quarterly Journal of Economics and Economic Policy”, Vol. 8, No. 2/2013, pp. 81-100; A.P. Balcerzak, Wptyw dziatalności regulacyjnej państwa w obszarze kreowania tadu konkurencyjnego na rozwój nowej gospodarki, [in:] A.P. Balcerzak, M. Moszyński (eds.), Aktywność regulacyjna państwa a potencjat rozwojowy gospodarki, Polskie Towarzystwo Ekonomiczne Oddział w Toruniu, Toruń 2009, pp. 71-106. 
common interpretations of such European policy guides as Lisbon Strategy ${ }^{2}$ or Europe 2020 Strategy 3 .

In this context, the article is devoted to the analysis of influence of $R \& D$ expenditures on quality of life in the case of European Union countries with dynamic panel modeling method. The aim of the paper is to verify the hypothesis that there is a positive relation between the level of R\&D expenditures (treated as a measure of input into knowledge creation) and quality of life in the European Union countries. The research takes into consideration the structural diversity between "old" and "new" members of the EU ${ }^{4}$. As a result, in the empirical part two separate econometric panel models were proposed: the first one for "old" members, and the second one for "new" member states that joined the EU in 2004. The research was done for the years 2004-2010.

As the main measure of quality of life Human Development Index was utilized. Thus, the article can be considered as a contribution to the discussion on the potential of HDI index for measuring the quality of live in narrow group of highly developed countries.

The article is a continuation of the previous research of the authors on the determinants of welfare in the reality of knowledge-based economy ${ }^{5}$.

${ }^{2}$ M. Olczyk, Structural Heterogeneity Between EU 15 and 12 New EU Members the Obstacle to Lisbon Strategy Implementation?, "Equilibrium. Quarterly Journal of Economics and Economic Policy”, Vol. 9, No. 3/2014, pp. 21-43; A.P. Balcerzak, D. Górecka, E. Rogalska, Taksonometryczna analiza realizacji strategii lizbońskiej w latach 2001-2005, „Wiadomości Statystyczne”, Vol. 6/2008, pp. 77-88; A.P. Balcerzak, Pozycja Polski w kontekście planu Europa 2020. Analiza z wykorzysta-niem metod porzqdkowania liniowego, "Studia Ekonomiczne. Zeszyty Naukowe Uniwersytetu Ekonomicznego w Katowicach”, Vol. 81/2011, pp. 31-41.

3 A.P. Balcerzak, Europe 2020 Strategy and Structural Diversity Between Old and Nerw Member States. Application of Zero-unitization Method for Dynamic Analysis in the Years 2004-2013, "Economics \& Sociology", Vol. 8, No. 2/2015, pp. 190-210.

${ }^{4}$ A.P. Balcerzak, Institutional Integration in the Sphere of Business Infrastructure in the European Union in the Years 2000-2008, "Journal of Reviews on Global Economics", Vol. 2/2013, pp. 131-141.

5 A.P. Balcerzak, M.B. Pietrzak, Wptyw efektywności instytucji na jakość życia w Unii Europejskiej. Badanie panelowe dla lat 2004-2010, „Przegląd Statystyczny”, Vol. 62, No. 1/2015, pp. 71-91; A.P. Balcerzak, M.B. Pietrzak, Efektywnośc instytucji a jakość życia w warunkach globalnej gospodarki wiedzy, "Prace Naukowe Uniwersytetu Ekonomicznego we Wrocławiu., Instytucje w teorii i praktyce", Vol. 405/2015 (forthcoming); A.P. Balcerzak, M.B. Pietrzak, Human Development and Quality of Institutions in Highly Developed Countries, Institute of Economic Research Working Papers, No. 156/2015; A.P. Balcerzak, M.B. Pietrzak, Efektywność instytucjonalna krajów Unii Europejskiej w kontekście globalnej gospodarki opartej na wiedzy, „Ekonomista”, 2016 (forthcoming). 


\section{HDI AS A MEASURE OF QUALITY OF LIFE}

Quality of life can be considered as a complex phenomenon that should not be identified only with one single measure such as GDP per capita ${ }^{6}$. This argument has gained significant recognition since the beginning of 90's of XX century and the inception of United Nations Development Programme? As a result of this initiative Human Development Index (HDI) was developed. In this approach, the problem of quality of life and welfare of citizens has been defined in a much broader manner than the simplified approach concentrating on GDP per capita or GDP growth commonly accepted in the end of XX century ${ }^{8}$.

In the case of HDI it is possible to modify the procedure of obtaining the values of the index, which is helpful when taking into account significant changes, both in the availability or quality of international data, or significant socio-economic changes of societies. In this method, three areas related to the quality of life of citizens are taken into consideration. The first area concentrates on the health of citizens, the quality of medical services, and is measured by average life expectancy. The second area expresses the quality

${ }^{6}$ See also M. Mościbrodzka, The Use of Methods of Multidimensional Comparative Analysis in Evaluation of the Standard of Living of Poland's Population in Comparison with Other Countries of the European Union, „Oeconomia Copernicana”, Vol. 5, No. 3/2014, pp. 29-47; M. Kuc, The Implementation of Synthetic Variable for Constructing the Standard of Living Measure in European Union Countries, „Oeconomia Copernicana”, Vol. 3, No. 3/2012, pp. 5-19; M. Kuc, The Use of Taxonomy Methods for Clustering European Union Countries Due to the Standard of Living, „Oeconomia Copernicana”, Vol. 3, No. 2/2012, pp. 5-23; A.P. Balcerzak, Taksonomiczna analiza jakości kapitatu ludzkiego w Unii Europejskiej w latach 2002-2008, „Prace Naukowe Uniwersytetu Ekonomicznego we Wrocławiu, Taksonomia 18 Klasyfikacja i analiza danych - teoria i zastosowania", Vol. 176/2011. pp. 456-467. For the quality of life in the lite of social utility functions and concept of measurement see: M. Moszyński, Jakość życia a nierówności dochodowe w Polsce i w Europie, [in:] S. Kowalik (ed.), Spoteczne konteksty jakości życia, Wydawnictwo Uczelniane Wyższej Szkoły Gospodarki w Bydgoszczy, Bydgoszcz 2007, pp. 81-102.

7 United Nations Development Programme, Human Development Report 1990, Human Development Research Paper.

${ }^{8}$ It is worth to notice that the problems of measuring quality of life and quality of human capital were the subject of interest of Polish econometricians already in 60's and 70's of XX century. See: Z. Hellwig, Procedure of Evaluating High-Level Manpower Data and Typology of Countries by Means of the Taxonomic Method, [in:] Z. Gostkowski (ed.), Towards a system of human resources indicators for less developed countries. Papers prepared for a UNESCO Research Project, The Polish Academy of Sciences Institute of Philosophy and Sociology, Ossolineum The Polish Academy of Sciences Press, Wrocław 1972, pp. 115-134. 
of the educational system. The last area concerns the present economic standard of living and is assessed with Gross National Income per-capita ${ }^{9}$.

Currently HDI index is generally recognized measure of quality of life and welfare for international comparisons ${ }^{10}$.

\section{R\&D AND ECONOMIC GROWTH IN REALITY OF KNOWLEDGE-BASED ECONOMY: SHORT OUTLINE OF CONTROVERSIES}

Last two decades have been the period of growing importance of knowledge-based economy concept $(\mathrm{KBE})^{11}$. As a result, it is believed that the developed countries can only stimulate their long-term economic growth, thus providing support for improvement of the quality of life of their citizens, when they are able to implement policies resulting in effective utilization of the potential of $\mathrm{KBE}^{12}$. From the theoretical point of view, the concept of $\mathrm{KBE}$ is based on the endogenous growth theory, where the essence of the argument can be summarized in the thesis that a policy supporting effective utilization of knowledge can lead to relatively high long-term sustainable growth even in the case of developed countries ${ }^{13}$. From the policy perspective,

9 Broader description of the HDI is also available in: A.P. Balcerzak, M.P. Pietrzak, Human Development..., op. cit.

${ }^{10}$ E. Babula, T. Kamińska (eds.), Uwarunkowania dobrobytu w sferze realnej, Wydawnictwo Uniwersytetu Gdańskiego, Gdańsk 2013, pp. 16-53; M. Brycz, Model zależności pomiędzy struktura sfery realnej a dobrobytem w Unii Europejskiej, [w:] E. Babula, T. Kamińska (eds.), Uwarunkowania dobrobytu w sferze realnej, Wydawnictwo Uniwersytetu Gdańskiego, Gdańsk 2013, pp. 16-53; 211-232; E. Ignaciuk, W. Kiwak, Źródta dobrostanu w krajach nordyckich, [in:] D. Filar, M. Brycz (eds.), Uwarunkowania równowagi gospodarczej i stabilności spotecznej w krajach nordyckich, Wydawnictwo Uniwersytetu Gdańskiego, Gdańsk 2015, pp. 135-142.

${ }^{11}$ An important econometric approach to operationalization of the concept can be found in: W. Welfe (ed.), Gospodarka oparta na wiedzy, Polskie Wydawnictwo Ekonomiczne, Warszawa 2007.

12 OECD, The Knowledge-based Economy, Paris 1996; OECD, The knowledge-based economy: a set of facts and figures, Paris 1999; M. Zielenkiewicz, Institutional Environment in the Context of Development of Sustainable Society in the European Union Countries, "Equilibrium. Quarterly Journal of Economics and Economic Policy”, Vol. 9, No. 1/2014, pp. 21-37; A.P Balcerzak, Efektywnośc systemu instytucjonalnego a potencjat gospodarki opartej na wiedzy, "Ekonomista", Vol. 6/2009, pp. 713-742; A.P. Balcerzak, E. Rogalska, Ochrona praw wtasności intelektualnej w warunkach nowej gospodarki, "Ekonomia i prawo", Vol. 4, No. 1/2008, pp. 71-87.

13 P.M. Romer, The Origins of Endogenous Growth, "Journal of Economic Perspectives", Vol. 8, No 1/1994, pp. 3-22; P.M. Romer, Endogenous Technological Change, "Journal of Political Economy”, Vol. 98, No. 5/1990, pp. S71-S102; T. Tokarski, Dwadzieścia lat renesansu teorii wzrostu gospodarczego. Na ile lepiej rozumiemy jego mechanizm, [In:] A. Wojtyna (ed.), Czy eko- 
there are two basic problems to consider: first of all, what are the tools that can be used for supporting KBE development; then, what methods of measurement of $\mathrm{KBE}$ can be used. As the nature of both these problems is very complicated, due to the editorial constraints of this paper it is not possible to discuss them reasonably ${ }^{14}$.

However, from the practical perspective, when one concentrates on the common among political decision makers interpretations of the Lisbon Strategy ${ }^{15}$ and Europe 2020 Strategy $^{16}$, which aim to be the main European strategies supporting $\mathrm{KBE}$ development, one can see that it is often believed that simple achievement of a given level of $\mathrm{R} \& \mathrm{D}$ expenditures is the most important automatic determinant of supporting knowledge-based growth. This approach tent to be based on the research results showing positive relations between R\&D investments on the national level and GDP growth or level of GDP per capita ${ }^{17}$. In practice, it often tents to be a simple political answer to the two above mentioned fundamental problems.

This simple concentration on the level of R\&D in relation to GDP does not take into consideration the complicated nature of interrelations between knowledge creation and GDP or wider welfare, neither does it take into consideration the different level of development and structural heterogeneity between EU countries ${ }^{18}$. To be precise, also the research results that show quite weak relations between R\&D expenditures and GDP growth from the international perspective are often neglected here ${ }^{19}$.

In this context, the empirical research presented in the next section of the article is devoted to the analysis of the influence of $\mathrm{R} \& \mathrm{D}$ expenditures

nomia nadqqża z wyjaśnieniem rzeczywistości?, Wydawnictwo PTE - Bellona, Warszawa 2001, pp. 213-245.

${ }^{14}$ Extensive discussion of these problems is available in: K. Piech, Wiedza i innowacje w rozwoju gospodarczym: w kierunku pomiaru i wspótczesnej roli państwa, Instytut Wiedzy i Innowacji, Warszawa 2009.

15 E. Okoń-Horodyńska, K. Piech (ed.), Unia Europejska w kontekście strategii lizbońskiej oraz gospodarki i spoteczeństwa wiedzy w Polsce, Instytut Wiedzy i Innowacji, Warszawa 2006.

${ }_{16}$ European Commission, Europe 2020 A strategy for smart, sustainable and inclusive growth, Communication from the commission, Brussels, 3.3.2010 COM(2010) 2020; Eurostat, Europe 2020 indicators, www.ec.europa.eu/eurostat (01.15.2015).

${ }^{17}$ L. Zienkowski, Gospodarka "oparta na wiedzy" - mit czy rzeczywistość, [In:] L. Zienkowski (ed.), Wiedza a wzrost gospodarczy, Wydawnictwo Naukowe Schoolar, Warszawa 2003, pp. $15-32$.

${ }_{18}$ B. van Pottelsberghe de la Potterie, Europe's REDD: Missing the Wrong Targets?, "Intereconomics", Vol. 43, No. 4/2008, pp. 220-225.

${ }^{19} \mathrm{~K}$. Piech, Knowledge economy and the long-term growth — are there any relations, [in:] K. Piech (ed.), Knowledge and innovation processes in Central and East European Economies, The Knowledge \& Innovation Institute, Warsaw 2007, pp. 27-42. 
on the quality of life in the EU countries. It takes into consideration significant structural differences between "old" and "new" member states in the context of KBE development.

The $\mathrm{R} \& \mathrm{D}$ expenditure (here research gross domestic expenditure on research and development - GERD) can be treated here as a single indicator that can help to approximate inputs into knowledge creation in analyzed countries. In spite of many weaknesses, this perspective is commonly used in empirical investigations evaluating the role of innovations systems in given economies ${ }^{20}$. However, it cannot be interpreted as the author' identification of $\mathrm{KBE}$ concept only with $\mathrm{R} \& \mathrm{D}$ investment.

\section{ECONOMETRIC DYNAMIC PANEL ANALISIS}

\subsection{THE DATA}

The HDI enables to classify the countries into quite homogenous groups with different level of quality of life ${ }^{21}$. In the original publication of the United Nations in 1990, the countries were classified into three categories:

a. low human development country (the value of HDI from 0 to 0,499 );

b. medium human development (the values $0,5-0,799$ );

c. high human development (the values $0,8-1$ ).

In the year 2009 an additional fourth class of countries was introduced that was grouping the countries with very high human development (values from 0,9 to 1 ). Additionally, a change in the method of setting the clusters was implemented. The authors of the HDI decided to resign from absolute values for the class intervals and introduced the procedure of relative class intervals that were set annually. In the year 2014 the following values of the class intervals were proposed: $(0-0,54)(0,55-0,699)(0,7-0,799)$ $(0,8-1)^{22}$.

20 Ibidem, p. 29.

${ }^{21}$ United Nations Development Programme, Human Development Report 2014, Human Development Research Paper.

${ }^{22}$ In the case of the empirical research done in this paper the class intervals for the year 2014 were used as the values of HDI received by the authors from HDRO were evaluated based on the method descripted in: ibidem; United Nations Development Programme, Technical Notes 2014, Human Development Research Paper. 
Tables 1 and 2 contain the values of HDI in the years 2004-2010 for two groups:

a. the "old" member states - the 14 countries that joined UE before the year $2004^{23}$ (table 1);

b. the "new" member states that joined UE in 2004 and 2007 (table 2).

In the case of the first group of economies only Portugal in the years 2004-2006 has been assigned to the category grouping high human development countries. In all cases, the "old" member states can be described as very high human development countries. In that group the average value of the HDI indicator increased in subsequent years from a value of 0.86 in 2004 to 0.879 in 2010 .

Table 1. The values of HDI indicator for "old" member States of the EU

\begin{tabular}{|c|c|c|c|c|c|c|c|}
\hline COUNTRY & 2004 & 2005 & 2006 & 2007 & 2008 & 2009 & 2010 \\
\hline Finland & 0.862 & 0.869 & 0.874 & 0.877 & 0.878 & 0.873 & 0.877 \\
\hline Sweden & 0.883 & 0.887 & 0.889 & 0.891 & 0.891 & 0.888 & 0.895 \\
\hline Denmark & 0.883 & 0.891 & 0.893 & 0.895 & 0.896 & 0.895 & 0.898 \\
\hline United Kingdom & 0.883 & 0.888 & 0.885 & 0.887 & 0.890 & 0.890 & 0.895 \\
\hline Netherlands & 0.884 & 0.888 & 0.895 & 0.901 & 0.901 & 0.900 & 0.904 \\
\hline Ireland & 0.885 & 0.890 & 0.895 & 0.901 & 0.902 & 0.898 & 0.899 \\
\hline Germany & 0.881 & 0.887 & 0.896 & 0.899 & 0.902 & 0.901 & 0.904 \\
\hline Austria & 0.845 & 0.851 & 0.857 & 0.861 & 0.868 & 0.870 & 0.877 \\
\hline Belgium & 0.862 & 0.865 & 0.868 & 0.871 & 0.873 & 0.873 & 0.877 \\
\hline France & 0.857 & 0.867 & 0.870 & 0.873 & 0.875 & 0.876 & 0.879 \\
\hline Spain & 0.838 & 0.844 & 0.848 & 0.852 & 0.857 & 0.858 & 0.864 \\
\hline Italy & 0.852 & 0.858 & 0.863 & 0.867 & 0.868 & 0.866 & 0.869 \\
\hline Portugal & 0.786 & 0.790 & 0.794 & 0.800 & 0.805 & 0.809 & 0.816 \\
\hline Greece & 0.839 & 0.853 & 0.859 & 0.857 & 0.858 & 0.858 & 0.856 \\
\hline \multicolumn{8}{|c|}{ DESCRIPTIVE STATISTICS } \\
\hline Mean & 0.860 & 0.866 & 0.870 & 0.874 & 0.876 & 0.875 & 0.879 \\
\hline Median & 0.862 & 0.868 & 0.872 & 0.875 & 0.8765 & 0.8745 & 0.878 \\
\hline Min & 0.786 & 0.790 & 0.794 & 0.800 & 0.805 & 0.809 & 0.816 \\
\hline Max & 0.885 & 0.891 & 0.896 & 0.901 & 0.902 & 0.901 & 0.904 \\
\hline
\end{tabular}

Source: Own preparation based on United Nations Development Programme, Human Development Report.

${ }^{23}$ In the case of the research Luxemburg due to the size of the economy was excluded from the group under evaluation. 
Also in the case of "new" member states, most of the economies in the years 2004-2010 were grouped into the class of countries with very high human development. Only Bulgaria and Romania in the whole period of analysis were classified into the group of countries with high human development. The average value of HDI indicator for the 10 "new" member states increased from 0,795 in 2004 to 0,822 in the year 2010. It can be seen that the average values of HDI indicator for the "new" member states are significantly lower than the average values of the indicator for "old" member states, which confirms the heterogeneity between the two groups.

Table 2. The values of $\mathrm{HDI}$ indicator for "new" member States of the EU

\begin{tabular}{|c|c|c|c|c|c|c|c|}
\hline COUNTRY & 2004 & 2005 & 2006 & 2007 & 2008 & 2009 & 2010 \\
\hline Estonia & 0.811 & 0.821 & 0.827 & 0.832 & 0.832 & 0.827 & 0.830 \\
\hline Lithuania & 0.798 & 0.806 & 0.814 & 0.820 & 0.827 & 0.833 & 0.829 \\
\hline Latvia & 0.777 & 0.786 & 0.796 & 0.804 & 0.813 & 0.814 & 0.809 \\
\hline Hungary & 0.799 & 0.805 & 0.810 & 0.813 & 0.814 & 0.816 & 0.817 \\
\hline Poland & 0.798 & 0.803 & 0.808 & 0.812 & 0.817 & 0.820 & 0.826 \\
\hline Czech Republic & 0.834 & 0.845 & 0.848 & 0.853 & 0.856 & 0.856 & 0.858 \\
\hline Slovenia & 0.851 & 0.855 & 0.861 & 0.865 & 0.871 & 0.875 & 0.873 \\
\hline Slovak Republic & 0.796 & 0.803 & 0.810 & 0.817 & 0.824 & 0.826 & 0.826 \\
\hline Bulgaria & 0.744 & 0.749 & 0.753 & 0.759 & 0.766 & 0.767 & 0.773 \\
\hline Romania & 0.742 & 0.750 & 0.759 & 0.769 & 0.781 & 0.781 & 0.779 \\
\hline \multicolumn{8}{|c|}{ DESCRIPTIVE STATISTICS } \\
\hline Mean & 0.795 & 0.802 & 0.809 & 0.814 & 0.820 & 0.822 & 0.822 \\
\hline Median & 0.798 & 0.804 & 0.81 & 0.815 & 0.8205 & 0.823 & 0.826 \\
\hline Min & 0.742 & 0.749 & 0.753 & 0.759 & 0.766 & 0.767 & 0.773 \\
\hline Max & 0.851 & 0.855 & 0.861 & 0.865 & 0.871 & 0.875 & 0.873 \\
\hline
\end{tabular}

Source: Own preparation based on United Nations Development Programme, Human Development Report.

In the table 3 and 4 the values of gross domestic expenditure on research and development (GERD) in relation to GDP for both groups of countries in the years 2004-2010 were presented, in the same form as it was presented in the case of HDI indicator.

In "old" members states the value of GERD to GDP around 3\% was only reached by the Scandinavian countries, Germany and Austria (table 3). The values of GERD between $1.23 \%$ and $2.24 \%$ were reached by such coun- 
tries as France, Belgium, the Netherlands, the United Kingdom and Ireland. The lowest values of GERD were reached in the Southern European countries such as Spain, Portugal, Greece and Italy. In case of that group, Greece can be considered as a negative example, where the values of GERD to GDP in the whole period are around $0,6 \%$. The data presented in table 3 confirms significant variation of the investments in R\&D among "old" member states. The average expenditure amounted to $1.896 \%$ in 2004 and increased to $2.171 \%$ in 2010 .

Table 3. The values of GERD for "old" member States of the EU

\begin{tabular}{|c|c|c|c|c|c|c|c|}
\hline COUNTRY & 2004 & 2005 & 2006 & 2007 & 2008 & 2009 & 2010 \\
\hline Finland & 3.45 & 3.48 & 3.48 & 3.47 & 3.70 & 3.94 & 3.90 \\
\hline Sweden & 3.58 & 3.56 & 3.68 & 3.43 & 3.70 & 3.62 & 3.39 \\
\hline Denmark & 2.48 & 2.46 & 2.48 & 2.58 & 2.85 & 3.16 & 3.00 \\
\hline United Kingdom & 1.67 & 1.70 & 1.72 & 1.75 & 1.75 & 1.82 & 1.77 \\
\hline Netherlands & 1.93 & 1.90 & 1.88 & 1.81 & 1.77 & 1.82 & 1.86 \\
\hline Ireland & 1.23 & 1.25 & 1.25 & 1.28 & 1.45 & 1.69 & 1.69 \\
\hline Germany & 2.50 & 2.51 & 2.54 & 2.53 & 2.69 & 2.82 & 2.80 \\
\hline Austria & 2.24 & 2.46 & 2.44 & 2.51 & 2.67 & 2.71 & 2.80 \\
\hline Belgium & 1.86 & 1.83 & 1.86 & 1.89 & 1.97 & 2.03 & 2.10 \\
\hline France & 2.16 & 2.11 & 2.11 & 2.08 & 2.12 & 2.27 & 2.24 \\
\hline Spain & 1.06 & 1.12 & 1.20 & 1.27 & 1.35 & 1.39 & 1.40 \\
\hline Italy & 1.09 & 1.09 & 1.13 & 1.17 & 1.21 & 1.26 & 1.26 \\
\hline Portugal & 0.74 & 0.78 & 0.99 & 1.17 & 1.50 & 1.64 & 1.59 \\
\hline Greece & 0.56 & 0.60 & 0.59 & 0.60 & 0.60 & 0.60 & 0.60 \\
\hline \multicolumn{8}{|c|}{ DESCRIPTIVE STATISTICS } \\
\hline Mean & 1.896 & 1.918 & 1.954 & 1.967 & 2.095 & 2.198 & 2.171 \\
\hline Median & 1.895 & 1.865 & 1.870 & 1.850 & 1.870 & 1.925 & 1.980 \\
\hline Min & 0.560 & 0.600 & 0.590 & 0.600 & 0.600 & 0.600 & 0.600 \\
\hline $\operatorname{Max}$ & 3.580 & 3.560 & 3.680 & 3.470 & 3.700 & 3.940 & 3.900 \\
\hline
\end{tabular}

Source: Own preparation based on UNESCO Institute for Statistics, www.uis.unesco.org (15.01.2015).

In the case of "new" members states GERD expenditures were much lower. Average expenditures were equal to $0.744 \%$ in 2004 and increased to a value of $1.013 \%$ in 2010. The highest level of GERD can be seen in Slovenia, Estonia, the Czech Republic and Hungary. For other countries the expanses 
are at a lower level and belong to the range from $0.39 \%$ to $0.8 \%$. It should be emphasized that in this group the median is much lower than the average, which means that more than half of the 10 countries are characterized by the values of GERD expenditures lower than average.

Table 4. The values of GERD for "new" member States of the EU

\begin{tabular}{|c|c|c|c|c|c|c|c|}
\hline COUNTRY & 2004 & 2005 & 2006 & 2007 & 2008 & 2009 & 2010 \\
\hline Estonia & 0.85 & 0.93 & 1.13 & 1.08 & 1.28 & 1.41 & 1.62 \\
\hline Lithuania & 0.75 & 0.75 & 0.79 & 0.81 & 0.80 & 0.84 & 0.80 \\
\hline Latvia & 0.42 & 0.56 & 0.70 & 0.59 & 0.61 & 0.46 & 0.60 \\
\hline Hungary & 0.88 & 0.94 & 1.01 & 0.98 & 1.00 & 1.17 & 1.17 \\
\hline Poland & 0.56 & 0.57 & 0.56 & 0.57 & 0.60 & 0.67 & 0.74 \\
\hline Czech Republic & 1.20 & 1.22 & 1.29 & 1.37 & 1.30 & 1.35 & 1.40 \\
\hline Slovenia & 1.39 & 1.44 & 1.56 & 1.45 & 1.65 & 1.86 & 2.11 \\
\hline Slovak Republic & 0.51 & 0.51 & 0.49 & 0.46 & 0.47 & 0.48 & 0.63 \\
\hline Bulgaria & 0.49 & 0.46 & 0.46 & 0.45 & 0.47 & 0.53 & 0.60 \\
\hline Romania & 0.39 & 0.41 & 0.45 & 0.52 & 0.58 & 0.47 & 0.46 \\
\hline \multicolumn{8}{|c|}{ DESCRIPTIVE STATISTICS } \\
\hline Mean & 0.744 & 0.779 & 0.844 & 0.828 & 0.876 & 0.924 & 1.013 \\
\hline Median & 0.655 & 0.660 & 0.745 & 0.700 & 0.705 & 0.755 & 0.770 \\
\hline Min & 0.390 & 0.410 & 0.450 & 0.450 & 0.470 & 0.460 & 0.460 \\
\hline $\operatorname{Max}$ & 1.390 & 1.440 & 1.560 & 1.450 & 1.650 & 1.860 & 2.110 \\
\hline
\end{tabular}

Source: Own preparation based on UNESCO Institute for Statistics, www.uis.unesco.org (15.01.2015).

\subsection{THE ECONOMETRIC DYNAMIC PANEL MODEL}

In order to verify the influence of $\mathrm{R} \& \mathrm{D}$ expenditure on quality of life in the EU countries the dynamic panel modeling procedure was used. In the preliminary stage of the estimation a few explanatory variables describing structural characteristics of developed countries in the context of $\mathrm{KBE}$ were taken into consideration. However, most of them were strongly correlated with GERD expenditure. Basing on the Bartosiewicz procedure, the authors decided not to use additional variables in the proposed model ${ }^{24}$. As a re-

${ }^{24}$ S. Bartosiewicz, Ekonometria. Technologia ekonometrycznego przetwarzania informacji, Państwowe Wydawnictwo Ekonomiczne, Warszawa 1978, pp. 28-54. Based on the approach proposed by Bartosiewicz the relations between HDI and different pillars of knowledge-based 
sult, HDI was treated as a dependent variable and GERD in relation to GDP was taken as an explanatory variable. Additional assumption was taken that among explanatory variable there should be delayed dependant variable. Specification of the model is presented by equation $(1)^{25}$ :

$$
H D I_{i, t}=\alpha_{0}+\alpha_{1} H D I_{i, t-1}+\beta_{1} G E R D_{i, t}+\eta_{i, t}+\varepsilon_{i, t},
$$

where:

$H D I_{i, t} \quad$ - a vector of dependent variable (HDI indicator);

$H D I_{i, t-1}$ - a vector of delayed dependent variable;

$G E R D_{i, t}$ - a vector of gross domestic expenditure on research and development in relation to GDP in chosen countries;

$\alpha_{0}, \alpha_{1}, \beta_{1}$ - the structural parameters of the model;

$\eta_{i, t} \quad-$ a vector of individual effects of panel model;

$\varepsilon_{i, t} \quad-$ a vector of disturbances.

After the specification of the panel model, the parameters of the model were estimated with the GMM system estimator with the asymptotic standard errors $^{26}$. The estimator is a development of first-difference GMM estimator ${ }^{27}$. In the estimation procedure, the estimation of both equations in first differences and equations in levels is done. In the research, the structural differences between the "old" and "new" member states was taken in the consideration. As a result, the estimation of the model was done separately for the "old" and "new" members. The results of the estimation procedure for the "old" member states are presented in the table 5. The results for the "new" members are presented in table 6.

economy such as quality of institutions influencing the incentives for KBE development was analysed in the following papers: A.B. Balcerzak, M.B. Pietrzak, Wptyw efektywności..., op. cit., pp. 71-91; A.P. Balcerzak, M.B. Pietrzak, Human Development..., op. cit.

25 B.H. Baltagi, Econometric analysis of panel data, John Wiley\&Sons Ltd., Chichester 1995, pp. 135-155.

${ }^{26} \mathrm{R}$. Blundell, S. Bond, Initial conditions and moment restrictions in dynamic panel data model, "Econometric Review", Vol. 19, No 3/1998, pp. 321-340.

${ }_{27}$ M. Arellano, S. Bond, Some tests of specification for panel data: Monte Carlo evidence and an application to employment equation, "Review of Economic Studies", Vol. 58, No. 2/1991, pp. 277-297. 
Table 5. The results of the estimation of parameters of the model 1 for "old" member states in the years 2004-2010

\begin{tabular}{|c|c|c|c|}
\hline VARIABLE & PARAMETER & ESTIMATION OF THE PARAMETER & $p$-VALUE \\
\hline$H D I_{i, t-1}$ & $\alpha_{1}$ & 0.830 & $\approx 0.000$ \\
\hline$G E R D_{i, t}$ & $\beta_{1}$ & 0.002 & $\approx 0.000$ \\
\hline STATISTICAL TESTS & STATISTICS OF THE TEST & $p$-VALUE \\
\hline Sargan Test & 13.511 & 0.811 \\
\hline AR(1) & -2.429 & 0.015 \\
\hline AR(2) & -1.383 & 0.166 \\
\hline
\end{tabular}

Source: Own estimation.

Table 6. The results of the estimation of parameters of the model 1 for "new" member states in the years 2004-2010

\begin{tabular}{|c|c|c|c|}
\hline VARIABLE & PARAMETER & ESTIMATION OF THE PARAMETER & $p$-VALUE \\
\hline$H D I_{i, t-1}$ & $\alpha_{1}$ & 0.732 & $\approx 0.000$ \\
\hline$G E R D_{i, t}$ & $\beta_{1}$ & 0.012 & $\approx 0.000$ \\
\hline \multicolumn{2}{|c|}{ STATISTICAL TESTS } & STATISTICS OF THE TEST & $p$-VALUE \\
\hline \multicolumn{2}{|c|}{ Sargan Test } & 8.522 & 0.981 \\
\hline \multicolumn{2}{|c|}{ AR(1) } & 0.408 & 0.682 \\
\hline AR(2) & -2.163 & 0.031 \\
\hline
\end{tabular}

Source: Own estimation.

After estimation of the parameters of two panel models, their statistical properties were verified. In that case, the Sargan test and tests for the serial autocorrelation of differences of residuals were done ${ }^{28}$. For both models Sargan test results indicate that overidentifying restrictions are justified. The values of obtained statistics at 13.511 (model for "old" member states table 5) and 8.522 (model for "new" member states - table 6) allow to conclude there are no grounds to reject the null hypothesis.

${ }^{28}$ R. Blundell, S. Bond, F. Windmeijer, Estimation in dynamic panel data models: improving on the performance of the standard GMM estimator, "Advances in Econometrics", Vol. 15/2000, pp. 53-91. 
In the case of the first model (table 5), the tests for the serial autocorrelation point to a negative statistically significant first-order serial correlation and not statistically significant second-order serial correlation ${ }^{29}$. The value of statistics pointing at the first-order serial autocorrelation at the level of -2.429 allows to reject the null hypothesis. On the other hand, the value of statistics pointing at the second-order serial autocorrelation at the level -1.383 support the conclusion that there are no grounds to reject the null hypothesis. This means that the applied GMM estimator is consistent and efficient.

In the case of the second model for the "new" member states the tests for the serial autocorrelation point to statistically insignificant first-order serial correlation and statistically significant second-order serial correlation. This means that the basic statistic properties of the model for using the system GMM estimator were not obtained. Thus, it does not allow to accept the results of estimation of parameters of the dynamic panel model. The obtained estimates of the parameters cannot be subject to interpretation ${ }^{30}$.

The verification of the statistical properties of the models allows to interpret the obtained results only in the case of the model for "old" member states that joined UE before 2004 (table 5). First of all, in the case of that interpretation one should remember about some weaknesses of the econometric procedure applied here - especially the relatively short period that is taken into consideration. With this assumption in mind, the parameter $\alpha_{1}$ is statistically significant, which confirms the autoregressive mechanism in the case of HDI. This result is consistent with the theory. The parameter $\beta_{1}$ is also statistically significant, which confirms the impact of $\mathrm{R} \& \mathrm{D}$ expenditure on the level of the quality of life in the "old" member states. The estimation value of the parameter $\beta_{1}$ indicates a positive relation, which can be interpreted as a confirmation of the thesis of the paper for the "old" member states in the analyzed period. In 14 most developed economies of the European Union increased R\&D investments have an effective impact on improving the quality of life of their inhabitants. The same cannot be confirmed in the group of "new" member states.

${ }^{29}$ B.H. Baltagi, op. cit., p. 158.

${ }^{30}$ It is possible that an increase of the sample for the next years could lead to obtaining the model with proper statistical characteristics. 


\section{CONCLUSIONS}

The aim of the article was to analyze the impact of R\&D expenditure on the quality of life in the European Union countries with the assumption of significant heterogeneity existing between "old" and "new" member states. It is commonly stated that in highly developed countries the investments in $\mathrm{R} \& \mathrm{D}$ at a given stage should result in higher innovativeness of economies, which should lead to higher quality of life. At the political level this relation is often considered as automatic, which could be seen in case of many interpretations of Lisbon Strategy or current Europe 2020 strategy.

As a result the hypothesis pointing at positive relation between $R \& D$ expenditures and the quality of life was econometrically tested for two groups of EU countries: the "old" and the "new" member states. The econometric dynamic panel modeling procedure allowed to confirm this hypothesis only in the case of highly developed "old" member states. The positive relation between investment in R\&D and welfare could not be positively verified in lower-developed "new" member states.

The results of the presented research cannot be treated as an argument that in less developed countries - here Central European economies - increasing the R\&D expenditure can be considered as a useless waste of resources, or that these countries should only concentrate on the possibilities of importing existing technologies. The research rather supports the thesis that the influence of $\mathrm{R} \& \mathrm{D}$ investments on welfare creation is not automatic, the transmission channels in this case are often complicated and are usually influenced by many institutional conditions. These factors should be remembered and taken into consideration in Central European countries in the process of forming national policies supporting $\mathrm{KBE}$ development. This research confirms that simply increasing the $\mathrm{R} \& \mathrm{D}$ investments without necessary complementary reforms and adjustments will not lead to automatic improvement of quality of people's life.

\section{BIBLIOGRAPHY}

Arellano M., Bond S., Some tests of specification for panel data: Monte Carlo evidence and an application to employment equation, "Review of Economic Studies", Vol. 58, No. 2/1991, http://dx.doi.org/10.2307/2297968.

Babula E., Kamińska T. (eds.), Uwarunkowania dobrobytu w sferze realnej, Wydawnictwo Uniwersytetu Gdańskiego, Gdańsk 2013. 
Balcerzak A.P., Efektywność systemu instytucjonalnego a potencjat gospodarki opartej na wiedzy, "Ekonomista", Vol. 6/2009.

Balcerzak A.P., Europe 2020 Strategy and Structural Diversity Between Old and New Member States. Application of Zero-unitization Method for Dynamic Analysis in the Years 2004-2013, "Economics \& Sociology", Vol. 8, No. 2/2015, http:// dx.doi.org/10.14254/2071-789x.2015/8-2/14.

Balcerzak A.P., Górecka D., Rogalska E., Taksonometryczna analiza realizacji strategii lizbońskiej w latach 2001-2005, "Wiadomości Statystyczne", Vol. 6/2008.

Balcerzak A.P., Institutional Integration in the Sphere of Business Infrastructure in the European Union in the Years 2000-2008, "Journal of Reviews on Global Economics", Vol. 2/2013, http://dx.doi.org/10.6000/1929-7092.2013.02.11.

Balcerzak A.P., Pietrzak M.B., Efektywność instytucji a jakość życia w warunkach globalnej gospodarki wiedzy, "Prace Naukowe Uniwersytetu Ekonomicznego we Wroclawiu., Instytucje w teorii i praktyce", Vol. 405/2015 (forthcoming).

Balcerzak A.P., Pietrzak M.B., Efektywnośc instytucjonalna krajów Unii Europejskiej w kontekście globalnej gospodarki opartej na wiedzy, "Ekonomista", 2016 (forthcoming).

Balcerzak A.P., Pietrzak M.B., Human Development and Quality of Institutions in Highly Developed Countries, Institute of Economic Research Working Papers, No. 156/2015.

Balcerzak A.P., Pietrzak M.B., Wptyw efektywności instytucji na jakośc życia w Unii Europejskiej. Badanie panelowe dla lat 2004-2010, "Przegląd Statystyczny", Vol. 62, No. $1 / 2015$.

Balcerzak A.P., Pozycja Polski w kontekście planu Europa 2020. Analiza z wykorzystaniem metod porzqdkowania liniowego, "Studia Ekonomiczne. Zeszyty Naukowe Uniwersytetu Ekonomicznego w Katowicach”, Vol. 81/2011.

Balcerzak A.P., Rogalska E., Ochrona praw własności intelektualnej w warunkach nowej gospodarki, "Ekonomia i prawo", Vol. 4, No. 1/2008.

Balcerzak A.P., Taksonomiczna analiza jakości kapitatu ludzkiego w Unii Europejskiej w latach 2002-2008, „Prace Naukowe Uniwersytetu Ekonomicznego we Wrocławiu, Taksonomia 18 Klasyfikacja i analiza danych - teoria i zastosowania”, Vol. 176/2011.

Balcerzak A.P., Wptyw dziatalności regulacyjnej państwa w obszarze kreowania tadu konkurencyjnego na rozwój nowej gospodarki, [in:] A.P. Balcerzak, M. Moszyński (eds.), Aktywność regulacyjna państwa a potencjat rozwojowy gospodarki, Polskie Towarzystwo Ekonomiczne Oddział w Toruniu, Torun 2009.

Baltagi B.H., Econometric analysis of panel data, John Wiley\&Sons Ltd., Chichester, 1995.

Bartosiewicz S., Ekonometria. Technologia ekonometrycznego przetwarzania informacji, Państwowe Wydawnictwo Ekonomiczne, Warszawa 1978.

Blundell R., Bond S., Initial conditions and moment restrictions in dynamic panel data model, "Econometric Review", Vol. 19, No 3/1998. 
Blundell R., Bond S., Windmeijer F., Estimation in dynamic panel data models: improving on the performance of the standard GMM estimator, "Advances in Econometrics", Vol. 15/2000, http://dx.doi.org/10.1016/s0731-9053(00)15003-0.

Brycz M., Model zależności pomiędzy struktura sfery realnej a dobrobytem w Unii Europejskiej, [w:] E. Babula, T. Kamińska (eds.), Uwarunkowania dobrobytu w sferze realnej, Wydawnictwo Uniwersytetu Gdańskiego, Gdańsk 2013.

European Commission, Europe 2020 A strategy for smart, sustainable and inclusive growth, Communication from the commission, Brussels, 3.3.2010 COM(2010) 2020.

Eurostat, Europe 2020 indicators, www.ec.europa.eu/eurostat (01.15.2015).

Hellwig Z., Procedure of Evaluating High-Level Manpower Data and Typology of Countries by Means of the Taxonomic Method, [in:] Z. Gostkowski (ed.), Towards a system of human resources indicators for less developed countries. Papers prepared for a UNESCO Research Project, The Polish Academy of Sciences Institute of Philosophy and Sociology, Ossolineum - The Polish Academy of Sciences Press, Wrocław 1972.

Ignaciuk E., Kiwak W., Źródta dobrostanu w krajach nordyckich, [in:] D. Filar, M. Brycz (eds.), Uwarunkowania równowagi gospodarczej i stabilności spotecznej w krajach nordyckich, Wydawnictwo Uniwersytetu Gdańskiego, Gdańsk 2015.

Janton-Drozdowska E., Majewska M., Effectiveness of Higher Education in the European Union Countries in Context of National Competitiveness, "Equilibrium. Quarterly Journal of Economics and Economic Policy", Vol. 8, No. 2/2013, http:// dx.doi.org/10.12775/EQUIL.2013.015.

Kuc M, The Use of Taxonomy Methods for Clustering European Union Countries Due to the Standard of Living, "Oeconomia Copernicana", Vol. 3, No. 2/2012, http:// dx.doi.org/10.12775/OeC.2012.006.

Kuc M., The Implementation of Synthetic Variable for Constructing the Standard of Living Measure in European Union Countries, "Oeconomia Copernicana", Vol. 3, No. 3/2012, http://dx.doi.org/10.12775/OeC.2012.012.

Madrak-Grochowska M., The Knowledge-based Economy as a Stage in the Development of the Economy, "Oeconomia Copernicana", Vol. 6, No. 2/2015, http://dx.doi. org/10.12775/OeC.2015.009.

Mościbrodzka M., The Use of Methods of Multidimensional Comparative Analysis in Evaluation of the Standard of Living of Poland's Population in Comparison with Other Countries of the European Union, "Oeconomia Copernicana", Vol. 5, No. 3/2014, http://dx.doi.org/10.12775/OeC.2014.018.

Moszyński M., Jakość życia a nierówności dochodowe w Polsce i w Europie, [in:] S. Kowalik (ed.), Spoteczne konteksty jakości życia, Wydawnictwo Uczelniane Wyższej Szkoły Gospodarki w Bydgoszczy, Bydgoszcz 2007.

OECD, The Knowledge-based Economy, Paris 1996.

OECD, The knowledge-based economy: a set of facts and figures, Paris 1999.

Okoń-Horodyńska E., Piech K. (red.), Unia Europejska w kontekście strategii lizbońskiej oraz gospodarki i spoteczeństwa wiedzy w Polsce, Instytut Wiedzy i Innowacji, Warszawa 2006. 
Olczyk M, Structural Heterogeneity Between EU 15 and 12 New EU Members the Obstacle to Lisbon Strategy Implementation?, "Equilibrium. Quarterly Journal of Economics and Economic Policy", Vol. 9, No. 3/2014, http://dx.doi. org/10.12775/EQUIL.2014.023.

Piech K., Knowledge economy and the long-term growth - are there any relations, [in:] K. Piech (ed.), Knowledge and innovation processes in Central and East European Economies, The Knowledge \& Innovation Institute, Warsaw 2007.

Piech K., Wiedza i innowacje w rozwoju gospodarczym: w kierunku pomiaru i wspótczesnej roli pañstwa, Instytut Wiedzy i Innowacji, Warszawa 2009.

Romer P.M., Endogenous Technological Change, "Journal of Political Economy", Vol. 98, No. 5/1990.

Romer P.M., The Origins of Endogenous Growth, "Journal of Economic Perspectives", Vol. 8, No 1/1994, http://dx.doi.org/10.1257/jep.8.1.3.

Tokarski T., Dwadzieścia lat renesansu teorii wzrostu gospodarczego. Na ile lepiej rozumiemy jego mechanizm, [in:] A. Wojtyna (ed.), Czy ekonomia nadq̨ża z wyjaśnieniem rzeczywistości?, Wydawnictwo PTE - Bellona, Warszawa 2001.

UNESCO Institute for Statistics, www.uis.unesco.org (15.01.2015).

United Nations Development Programme, Human Development Report 1990, Human Development Research Paper.

United Nations Development Programme, Human Development Report 2014, Human Development Research Paper.

United Nations Development Programme, Technical Notes 2014, Human Development Research Paper.

van Pottelsberghe de la Potterie B., Europe's RED: Missing the Wrong Targets?, "Intereconomics", Vol. 43, No. 4/2008, http://dx.doi.org/10.1007/s10272-008-0254-y.

Welfe W. (ed.), Gospodarka oparta na wiedzy, Polskie Wydawnictwo Ekonomiczne, Warszawa 2007.

Zielenkiewicz M., Institutional Environment in the Context of Development of Sustainable Society in the European Union Countries, "Equilibrium. Quarterly Journal of Economics and Economic Policy", Vol. 9, No. 1/2014, http://dx.doi. org/10.12775/EQUIL.2014.002.

Zienkowski L., Gospodarka "oparta na wiedzy" - mit czy rzeczywistośc, [in:] L. Zienkowski (ed.), Wiedza a wzrost gospodarczy, Wydawnictwo Naukowe Schoolar, Warszawa 2003. 